\title{
The Contestation of Muslim and Special Autonomy in Papua
}

\author{
Cahyo Pamungkas \\ Lembaga Ilmu Pengetahuan Indonesia (LIPI), Jakarta \\ cahyopamungkas_lipi@yahoo.com
}

\begin{abstract}
Abstrak
Identitas politik orang Papua dianggap sebagai ras Melanesia dengan ciri-ciri yaitu orang yang berkulit hitam, rambut keriting dan beragama Kristen. Identitas politik semacam itu dipergunakan oleh orang-orang elit Papua sebagai alat perpolitikan, namun politik identitas tersebut menjadi agak berbahaya berkaitan dengan identitas Papua yang inklusif dan toleran. Pada kenyataannya, orang Papua asli dapat dibedakan menurut identitas agama mereka yang terdiri dari orang Kristen, Katolik dan Muslim. Hal tersebut menandakan bahwa ruang perdebatan untuk menentukan politik identitas Papua ditandai dengan proses negosiasi Kristen Papua (orang Papua yang beragama Kristen) dan Muslim Papua (orang Papua yang beragama Islam). Perbedaan penafsiran dari identitas Papua dibangun oleh para intelektual dan elit Papua yang ingin bersinggungan langsung dengan pengembalian identitas asli (repapuanization). Artikel ini akan mengarah pada metode orang Islam dan Kristen Papua dalam mempertahankan identitas mereka dan mendapatkan pengakuan sebagai bagian dari orang Papua. Artikel ini mencoba menjawab tiga pertanyaan terkait dengan (1) bagaimana Muslim Papua membangun identitas budaya mereka pada masa otonomi khusus; (2) bagaimana Muslim Papua memperjuangkan identitas budaya mereka bersamaan dengan Muslim imigran; dan (3) bagaimana Muslim Papua memperjuangkan identitas budaya mereka bersama dengan orang Kristen Papua.
\end{abstract}

Kata kunci: Papua, Kristen, Muslim, Identitas. 


\section{Introduction}

This article is a summary of thesis research in the Department of Sociology, the University of Indonesia in 2008, sponsored by the Friedrich Ebert Stiftung (FES). The topic starts by the fall of New Order that defining the Papuan political identity to distinguish with the migrants in Papua. The Papua political identity is perceived as Melanesian race that is black, curly, and Christian. ${ }^{1}$ Such political identity was exploited by Papuan elites as political instrument, but it is rather dangerous in developing an inclusive and tolerant Papua identity. The Papua ethnic groups in Fak-fak, Kaimana, Raja Ampat, Biak, Serui, and Sorong that are Muslim and have a long interracial marriage history will be excluded from the definition. The formal debate on Papua identity can be traced in the following case. MRP (Majelis Rakyat Papua) (Papua People Assembly), rejected the originality of one of the vice governor's candidate in provincial governor election 2005, because one of them is a mixed-blood of Arab-Fak-fak. ${ }^{2}$

The Indonesian law No. 21/2001 on Special Autonomy only explained that the native Papuan is the one coming from ethnic groups of Melanesian race or the migrant who being accepted and recognized by ethnic groups in Papua. However, in reality, the native Papuan can be differentiated according to their religion consist of Christian, Catholics, and Muslim. It implicated that debate's arena to determine the Papua political identity is marked by negotiating processes between the Christian Papua and the Muslim Papua. The difference of interpretation on Papua identity is constructed by intellectual and elites of Papua that going hand in hand with the re-Papuanization. The borders of races, ethnic groups, and religions become relevant in the moment of special autonomy. In this context, the Muslim Papua questioned the definition

\footnotetext{
1 Timo Kivimaki and Rubern Thorning, "Democratization and Regional Power Sharing in Papua/Irian Jaya: Increased Opportunities and Decreased Motivations for Violence", in Asian Survey, Vol. XLII, No. 4 (2002), 651-672; Muridan S Widjojo, "Dari Persipura ke Otsus: Masyarakat Sipil Papua dan Agenda Damai", in Adriana Elisabeth (ed.), Agenda dan Potensi Damai di Papua (Jakarta: LIPI Press, 2005).

${ }^{2}$ Kompas, 19 November 2005.
} 
and meaning of the native Papua that being identic with the Christian Melanesian ethnic groups.

The article will concern on the strategies of the Muslim Papua to get into recognition in Papua in the period of Special Autonomy. This question leads some other inquiries on how does the Muslim Papua construct their cultural identity in the period of Special Autonomy; how does the Muslim Papua deal with their cultural identity with the migrant Muslim; and how does the Muslim Papua contest their cultural identity with Christian Papua. The term of identity refers to Bourdieu (1991) that identity is practical category. It is objectified mental representations through social practices and internalized objective cultural signs through symbolic manipulation strategy. Identity construction is conducted via symbolic and power struggle among social actors.

The Muslim Papua is adat community who believe in Islam; meanwhile the Christian is adat community who embrace Christian and Catholic. Adat community, according to Law No 21/2001, is defined as the members of the native Papua, living in and bound to a certain area with high solidarity among its members. The Muslim Papua is represented by Papua Muslim Assembly or MMP (Majelis Muslim Papua). ${ }^{4}$ The Christian Papua refers to Theology Institute of IS Kijne, Theology Institute of Walter Post, Evangelical Church of Papua (GKIT), Baptist church, the associations of Church in Manokwari, the associations of churches in Pegunungan Jayawijaya, and Bishop of Jayapura. The terms of Christian in Papua refers to both Christians and Catholics although there are many differences between them. The migrant Muslim is the people who was born outside Papua and believe in Islam. They are represented by the Islamic organizations such as MUI (Indonesian Ulama Assembly), Muhammadiyah, Nahdlatul Ulama, ICMI (Indonesia Muslim Intellectual association), and Yapis (Islamic Education Foundation in Papua).

The terms of identity contestation are struggle among social actors or institutions in demanding their cultural identity legitimate in the

\footnotetext{
${ }^{3}$ Based on Law No. 21/2001, Adat is the hereditary customs acknowledged, adhered to, institutionalized and maintained by the Local adat community.

${ }^{4}$ As a note, there are a few of migrant Muslim who occupying the first echelon in this organization mainly secretary general and treasury general.
} 
field of identity politics. It consists of the field of Islamic organizations and the field of politics and religion. This research is addressed to find out and specifically concerning with the establishment of Papua Muslim Assembly on April 13, 2007. The data collection method includes observation, in-depth interview, and archival research. The fieldwork was carried out in Jayapura in the period of February 17 - April 17, 2008. And the resources of persons are a number of elites of Islamic organizations, churches, cultural communities, and local politicians.

\section{Social Context in Papua}

The name of Papua derives from word of puah-puah. It means curly where the modern encyclopedia of British, Dutch, and Spain took starting point from this meaning. ${ }^{5}$ For example, in the British-Malay dictionary Von De Wall, 'papoewab' means (1) New Guinea and (2) curly people. The meaning of Papua etymologically can be traced in Biak language. FC Kamma, Dutch missionaries and historian, said that the people of Biak and Numfor called Raja Ampat archipelago as Sup $i$ babwa' that it means as a low land or a land of the sunset. ${ }^{6}$ Idea that native Papua is different race with other Indonesian people and have the right of self-determination, stemmed from the Dutch. ${ }^{7}$ It rose in 1930 when the great depression took place and elicited a labor competition between Indo-European and native Indonesian. This condition brought forward the significance of territorial basis for Indo-European. Then, it was founded new institutions and essays that Papua native are Melanesia race that different with other Indonesian people. ${ }^{8}$

The population of Papua Province (minus West Papua) in 2006 is 2.524.275 people. They embrace Christian (55\%), Catholics (30\%),

\footnotetext{
${ }^{5}$ Sollewijn Gelpke, "On the origin of the name Papua" in Bijdragen tot de Taal-, Land- en Volkenkunde, No: 2, Leiden (1993). See further in www.kitlv-journals.nl/ accessed 24 October 2007.

${ }^{6}$ Ibid.

7 Arend Lijphart, “The Indonesian Image of West Irian”, in Asian Survey, Vol. 1, No. 5, (1961), 9-16.

8 Octavianus Mote and Danilyn Rutherford, "From Irian Jaya to Papua: the Limit of Primordialism in Indonesia's Troubled East" in Indonesia, No. 72, October (2001), 118.
} 
Islam (14\%), Hindu (0, 17\%) and Buddhist (0, 39\%). The Muslim population in Papua generally is the migrant coming through transmigration policy and spontaneous migration. ${ }^{9}$ If the migrant in Papua, in 1971, is 4\% from total population of Papua, they become $35 \%$ in 2000. ${ }^{10}$ Fifteen years ago, $90 \%$ of Papua is native people. In 2003, cities and town in Papua are inhabited by migrant (90\%) where they dominate the economy trade, labor, transportation, and private offices, and other business. ${ }^{11}$ The social and economic context in Papua describes that economic structure has placed native Papua in subordinated position and migrant in dominant position. The objective relations in economic structure have contributed in identity formation based on class that is between the native and the migrant.

Meanwhile, social and political context is also significant in Papua. The debates between Indonesia and Papua nationalist about history of Papua integration based on Indonesia and Papua political identity construction. ${ }^{12}$ For Indonesia nationalist, Papua is part of Indonesia nation regardless races differences. Meanwhile, for Papua nationalist, Papua-ness based on racial differences between Indonesian and Papuan. According to them, Act of free choice in 1969 had been manipulated by national government of Indonesia through unfair selection of 1.025 Papua representatives. Besides that, West Papua state has been proclaimed since 1961. Therefore, Papua-ness is constructed political identity by experiences of Papua during the colonial time and being addressed as anti-thesis of Indonesia-ness. ${ }^{13}$ The Papuan elites

\footnotetext{
9 Suparto Iribaram, "Dinamika Kehidupan Umat Islam dalam Pembangunan di Papua", dalam Jurnal Jabal Hikmah, Vol. 1, No. 1, (2008), 5.

${ }^{10}$ Rodd McGibbon, "Secessionist Challenges in Aceh and Papua: Is Special Autonomy the Solution?", in www.eastwest.org/ accessed on_24 October 2007.

${ }^{11}$ Kompas, 23 February 2003.

12 Adriana Elisabeth (ed.), Pemetaan Peran dan Kepentingan Para Aktor Dalam Konflik di Papua (Jakarta: Lembaga Ilmu Pengetahuan Indonesia, 2004), 22-37; Kivimaki, Timo and Rubern Thorning, "Democratization and Regional Power", 652.

13 Richard Chauvel, "Constructing Papuan Nationalism: History, Ethnicity, and Adaptation", in Policy Studies East-West Center Washington, in www.east-westcenter.org./ accessed 24 October 2007.
}

30 Cahyo Pamungkas - The Contestation of Muslim and Special Autonomy in Papua 
think that the Papuan was object in the decolonization without being as participants. ${ }^{14}$

The presence of Indonesia government in Papua since 1962 raised political violence in Papua. ${ }^{15}$ The political violence is objective experiences being undergone by native Papua as political consequences of government strategy to coping with the separatism led by the Free Papua organization (OPM). The experiences generate collective memory of suffering called as "memoria Passionist". ${ }^{16}$ Gibbons (2006) stated that Papua-ness became stronger in the time of New Order because of the development. As an instrument of modernization, economic development has marginalized the native Papua and benefited to the migrant. The special autonomy is not a way to coping with the separatism, but it is a result from political negotiation between Indonesia nationalist and Papua élites, so it represents unilateral concessions from Jakarta and has no relation with main political powers advocating Papua independence such as Free Papua organization and Papua presidium Council (PDP). ${ }^{17}$ Related with the political context, this study assumes that migrant political orientation tends to the Indonesian nationalist and Papuan native tends to Papua nationalist.

Moreover, economy and political context, cultural context is important to find out. Interviews data shows that native Papua still embraces Melanesian's system of belief due to the Christian and Islam only grow to be 'a family religion'. ${ }^{18}$ It still exists in the modern everyday life of Christian Papua and Muslim Papua as customs and cultural traditions. Whiteman explained that the most central value for culture and religion of Melanesia is a continuity of life, preservation of life,

\footnotetext{
${ }^{14}$ Ibid., 82.

15 Adriana Elisabeth (eds.), Pemetaan Peran, 38.

16 Benny Giay, Misi Gereja dan Budaya Kekerasan di Tanah Papua, Hidup dan Karya Pdt Herman Saud Ketua Sinode GKI di Tanah Papua Masa Bakti 1996-2005 (Jayapura: Deiyai, 2006), 6.

${ }^{17}$ Rodd McGibbon, "Secessionist Challenges", viii.

${ }^{18}$ Jose Mansoben, interview, Jayapura, March $4^{\text {th }}$, 2008; JF Onim, interview, Jayapura, April $7^{\text {th }}, 2008$.
} 
protection of life, and celebration of life. ${ }^{19}$ It turns into sources of values that can bring together Papua people that embrace Christian or Islam. In the colonial time, inter-religion differences were not significant. Although there are many religions in Fak-fak and Kaimana, the native Papua is bounded with cultural tradition and kinship. It supported their modern religion practices develop into more tolerant, open, and moderate. It is identified as habitus of religion of the native Papua.

The Christian came into Papua through Manokwari when two German missionaries C.W. Attouw and G.J. Geissler harbored in Mansinam Island on February 5, 1855. Catholic cross the threshold to Papua in 1896 in Merauke, but missionary activities was started on in 1902 under Ordo of Pure Heart (MSC) and Ordo of Dina Sister (OFM). ${ }^{20}$ According to Mansoben, the attendance of Christian in Papua purpose as unites Melanesian tribes into one common community. Thomas Arnold said that amount of Papua tribes in GebiIsland has been Islamized by Moluccas migrant since 1606. ${ }^{21}$ The Spaniard sailor, Louis Vaes de Torres, found Muslim traders from Ternate, Tidore and Makassar that preaching Islam in Onim Fak-fak. ${ }^{22}$ The sultanate of Bacan in Northern Moluccas has occupied western Papua such as Waigeo, Misool, Waigama, and Salawati since the16th century. FC Kamma (1981: 61) also said that in 1500, the Papua people on western and northern coastal lost their sovereignty since Sultan Tidore appointed the deputies to collect tributary like slaves and Cenderawasib bird. ${ }^{23}$ Islam is recognized as the first religion came in Papua but their roles are very limited in developing of civilization due to Islam was developed by personal relations.

19 Agus Alua, Papua Barat Dari Pangkuan Ke Pangkuan, Suatu Ikbtisar Kronologis: Seri Pendidikan Politik Papua No. 2, (Jayapura: STFT Fajar Timur, 2006), 14.

20 Bondan Soedarto, Sejarah Perjuangan Rakyat Irian Barat, Jayapura: Uncend and Bappeda Provinsi Irian Jaya, 1989), 53-61.

21 Ali Athwa, Islam atau Kristenkah Agama Orang Irian? (Jakarta: Pustaka Da’i, 2004), 44.

${ }^{22}$ Bondan Soedarto, Sejarah Perjuangan, 57.

${ }^{23}$ F. C. Kamma, Ajaib di Mata Kita Jilid I (Jakarta: BPK Gunung Mulia, 1981), 61. 
Refer to Bourdieu, Papua is a social space; consist of a variety of fields. ${ }^{24}$ The field of politics since colonial time until nowadays has shaped the Papua political identity. Before colonialism, the tribe's identity turns out to be the dominant identity. The special autonomy is political affirmation for the native Papua to go into the field of politics. However, the field of identity politics in Papua are lived in by Muslim Papua, Muslim migrant, Christian Papua, and Christian migrant. The study only focuses on how the Muslim Papua, between Muslim and Christian Papua, creates their cultural identity in the field of identity politics. The next part will explain how the Muslim Papua constructs their identity through political discourse and establishment of Papua Muslim Assembly.

\section{Identity Construction of the Muslim Papua}

The Muslim Papua is symbolized by Papua Muslim Assembly (Majelis Muslim Papua (MMP)), that is a continuity from Papua Muslim Solidarity (Solidaritas Muslim Papua (SMP)) founded by 47 Muslim elites in Papua on November 21, 1999 such as Thaha M. Alhamid, Aroby A. Aituarouw, L. Anum Siregar, and Sayyid Fadhal Alhamid. SMP is one of the ways of Muslim Papua in building their identity in Papua. While the Christian Papua was successful in developing Papua nationalism that equal with Indonesia nationalism, the Muslim Papua was conscious of their position in the contestation of political identity between Indonesianess and Papua-ness. The establishment of SMP could not be separated from the political context of the awakening of the native Papua in 1999. A few of months before the formation of SMP, exactly in February 26, 1999, 100 Papuan elites took on national dialogue with President BJ Habibie and express political declaration that they wanted to go out from Indonesia. ${ }^{25}$

\footnotetext{
24 Bourdieu, Pierre, Language and Symbolic Power, ed. John B. Thompson, trans. Gino Raymond and Matthew Adamson (Cambridge: Harvard University Press, 1991), 9.

25 Agus Alua, Dialog Nasional Papua dan Indonesia 26 Februari 1999: Seri Pendidikan Politik Papua No. 2, (Jayapura: STFT Fajar Timur, 2002), 10.
} 
The political tension in Papua in 1999 also came across with the formation of dominant political discourse in mass media that Islam was one and identical with Indonesia, military, and migrant. Meanwhile, Papua is matching with Christian, Melanesian race, and separatist. According to L. Anum Siregar, Secretary General of MMP and chairperson of ALDP (Alliance of Democracy for Papua), it was constructed for the reason that encountering experiences between Papua native and Indonesian people through annexation, transmigration, and military operation. It was reinforced by NGOs and churches opinion that the identification of the native Papua as Melanesian, Christian, and separatist rooted in political violence in Pegunungan Tengah where the region was occupied by military operation.

The rationale of establishment of MMP is as follow. The first is to counter discourse against the dominant political identity discourse that Islam is identical with Indonesia. The term of Muslim Papua is closer with the native Papua because in reality, not all Muslims are in the side of Indonesia and not all of native Papua are Christian. The second is as communication's bridge between Muslim migrant with Christian Papua society. It provides evidence that social construction of identity about Indonesia is Islam and Papua-Christian is not right. The third is that MMP is dealing with the recognition of the native Papua. It implicates for rights and liabilities inherited by the native Papua native including tribes' territory (tanah adat) or the right over certain territory. The fourth, MMP is a form of critique against Islamic organizations mainly MUI which tends to empower of Muslim migrant and has not root in Muslim Papua communities. The fifth, MMP is an Islamic based institution for advocating human rights and economic disparity between the native Papua and the migrant.

Theological construction of MMP is not different with other Islamic organizations that every Muslim should be rahmatan lil alamin (blessing for all universes). On individual level, the vision developed is increasing goodness and struggling for people welfare in Papua. In its declaration, MMP convey messages to the non-Muslim communities as follow: (1) MMP does not want to create an exclusive community; (2) MMP does not put into practice of Islamization; (3) MMP does not 
extend a religion fundamentalism. The roles, which will be taken by MMP, are cooperation with government to insist on justice and people welfare, and collaboration with leader of church in composing Papua as peace land. The objectives of MMP as follow. The first, to make structure of society and human solidarity among all Muslim in everyday life, based on basic principles of Islam blessing for all universes and for religion tolerance. The second is putting together Muslim welfare through advance of education and health services, economic independence, and environment preservation, social, culture emancipation, and human rights enforcement.

The term of Muslim Papua is a politically construction. It comes into sight to differentiate with migrant Muslim. Differences between the Muslim Papua and Muslim migrant does not seem apparently in Fak-fak and Kaimana, but look predominant in other regencies and cities of Papua mainly in Jayapura. In this perspective, The Muslim Papua means as Muslim that does not create cultural distances with the native Papua who majority are Christian. It is often expressed as religion habitus of Muslim Papua i.e. moderate, open, tolerant, inclusive, and put emphasis on dialogue. The Muslim Papua regards their culture as a communication's tool among Papuan people and do not put religion as difference in everyday life. Islam for Muslim Papua brings together with culture of the native Papua. This vision of Islam like this can be found in social practices of MMP that stating Merry Christmas with Christian communities in December 25, 2007.

MMP is also identical with icon of human rights struggling over the native Papua due to a main part of central committee of MMP are dwelled in by activist from ALDP (Democracy Alliance for Papua), an NGO that advocate human rights centered on Jayapura. Refers to Bourdieu, advocating of human rights can be categorized as social practices of MMP. Starting from these social practices, political habitus of MMP can be categorized as criticize, anti-status quo, and antiviolence. From the kinds of capital, two most significant are social and symbolic capital. The first, MMP has strong relation with Christian organizations and NGOs in Papua. Even, the founder of MMP, Thaha M. Alhamid is secretary general of Papua Presidium Council (PDP), an 
institution of Papua political independence movement. It has made MMP more being accepted in Christian Papua communities than Islamic organizations. The second is recognition that basis and members of MMP is the native Papua from seven cultural territories in Papua.

The establishment of MMP can be interpreted as an effort of the Muslim Papua to put up their dream in the future by looking back their history. For a community in subordinated position such as MMP, history is a foundation to search their identity against the legitimate definition of identity constructed by the dominant group. The interpretation over history by the dominant groups has function as legitimating instrument over domination relations. Sociologically, MMP represents Muslim Papua that being in subordinated position to get recognition of their cultural identity. By means of Bourdieu perspectives, the founding of MMP can be read between the lines as creation of symbolic capital. It is defined as a set of respect owned by a social actor so associate on his positions in social structure that is recognized as legitimate. The acknowledgment of Muslim Papua as the Papua native is understood as recognition over the rights of the Muslim Papua to have roles in Papua as the Christian Papua. Nevertheless, the problem is the identity discourse of the Muslim will deal with the dominant identity discourse of Muslim migrant and Christian Papua. The following section will shed a light how the Papua-Muslim contest their identity against the Muslim migrant.

\section{Muslim Papua and Muslim Migrant}

The field of Islamic organization is a contest between migrant based Islamic organizations and MMP in performing religious social practices and defining Islam-ness way of life that being recognized as legitimate in Papua. The migrant based Islamic organizations are MUI (Majelis Ulama Indonesia), Yapis (Yayasan Pendidikan Islam di Tanah Papua), Muhammadiyah, NU (Nahdlatul Ulama), ICMI (Ikatan Cendekiawan Muslim Indonesia), Hidayatullah, HTI (Hiz̧but Tahrir Indonesia), Assalam, LDII (Lembaga Dakwah Islam Indonesia), and BKPRMI (Badan Koordinasi Pemuda dan Remaja Masjid Indonesia). On the other hand, the significant 
Islamic organizations in this field are MUI, Muhammadiyah, Yapis, NU, and ICMI. MUI is an Islamic institution that being acknowledged by the national government as represents Islamic people, whereas Yapis is accepted by local government in their working for education in Papua. However, Muhammadiyah and NU are accredited due to their longer time presence in Papua since early integration. ICMI is renowned because their chairperson, Musa'ad was one of actors in negotiating special autonomy of Papua. If being observed from their political habitus, Islamic organizations have many similarities i.e. not critical and pro-status quo. Their religion social practices are education, development of cooperation, spread of Islamic thought and Indonesia political orientation, and wearing Islamic symbols. They are influenced by their political habitus and their capital (material, cultural, social, and symbolic), their interest to maintain Indonesia as a political unitary, and the field of Islamic organizations that put them in a dominant position put side by side with MMP.

MMP has dissimilar habitus that are criticizing, anti-status quo, and anti-violence that stand for sustaining Papua as land of peace. Social practices from MMP individuals, such as advocating of human rights and taking part in political movement of Papua people such as PDP and DAP, are influenced by their political habitus and the field of Islamic organizations that situate them in subordinated position. The marginal position of MMP in this field is due to they are minus in all kind of capital. Since the field of Islamic organizations is within the field of politics, so the latter influences the former. Consequently, the objective relations between Islamic organizations and MMP correspond to the objective relations between Indonesia and Papua nationalist.

One way to get across identity contestation among MMP and Islamic organizations in the field of Islamic organizations is uttering Merry Christmas to the Papua-Christian. Saying Merry Christmas is prohibited for the reason that it recognizes indirectly the other God except Allah. Therefore, not all of the Islamic organizations ever say Merry Christmas to the Christian. MUI, under Buya Hamka in 1974, has declared as forbidden statements for Islamic organization to saying Merry Christmas since it is indistinguishable with celebration of God's 
birthday. Nonetheless, MMP has a different principle that saying Merry Christmas can be justified for Islamic communities in Papua as expression of culture and it also has become cultural tradition for both Papua-Muslim and Papua-Christian. The action of MMP to fix banner about Merry Christmas on December 25, 2007 is inseparable part from culture of the native Papua. The message of this banner is that MMP expressed their difference with their counterpart, the Muslim migrant.

In addition, if being analyzed from the discourse of Islam-ness, almost of Islamic organizations has set up from the view of $A l$ Qur'an that Islam is rabmatan lil 'alamin and not being bounded by ethnicity. Nevertheless, the translation of rabmatan lil 'alamin is different in social practices of Islamic organizations. NU takes Islam rahmatan lil 'alamin as Islam that is more moderate and acculturation with local culture. According to secretary of NU Papua, NU provides understanding about moderate Islam, and initiates agenda of dialogue. Opposite with NU, Muhammadiyah centers of its attention on assimilation of culture with Islamic values. The Muhammadiyah activities lay emphasis on elimination of cultural tradition that opposite with Islamic principles. For the moment, different with Muhammadiyah and NU, MMP stated that Islam should be rabmatan lil Papua. MMP interprets Islam rabmatan lil 'alamin as Islam rahmatan lil Papua. It means that Islam will be blessing for all universes if Islam can be blessing first for the people of Papua. This point of view does not mean that MMP is creating ethnicity based Islamness, but MMP put Islam in its social context, that is Papua people.

If it is reflected on their political discourse, Islamic organizations are inclined to political orientations of maintaining NKRI (Unitary State of Republic Indonesia). It can be understood that politics of Islamic organizations represent Muslim migrant that is politics of the state. Thus, in the field of Islamic organizations as take place in the field of politics, Islamic organizations do not question of political status, history, and political identity of Papua. As consequence, there is closeness in political orientation between Islamic organizations and government officials in Papua to keep up political integration of Papua according to government perspective. In the field of Islamic organizations, The Muslim migrant takes up dominant position because they hold up the legitimate 
dominant political discourse that that NKRI is ultimate. It is a symbol of the Indonesia political identity.

Generally speaking, political discourse of MMP is upholding Papua as land of peace that terminologically is near with political orientation of Church and NGOs in Papua. As subsequently, MMP is not associated with the matters of political integration or pro-Papua freedom, but MMP centers their attention on establishment of justice in the context of making Papua as a land of peace. If it is traced further, political discourse that Papua as land of peace has set in MMP between Indonesia and Papua nationalist positions in the field of politics. The national government and military often take account of this middle group inside the Papua nationalist. ${ }^{26}$ If MMP is laid on a broader the field of politics, MMP represent the Papua political identity.

The Indonesia political identity operates symbolically to cover the power interest keeping national integration. It is changed into symbolic power in the field of Islamic religion and the broader field of politics in Papua. Furthermore, it determines objective positions of migrant based Islamic organizations and MMP in the field of Islamic organizations. The organizations bear this political identity will rest the dominant position. Refers to Smith, The Muslim migrant seems to threat nationalism as theological construction or political religion. ${ }^{27}$ Therefore, they could not distinguish obviously between nationalism and Islamic principles. It can be understood remind that their existence in Papua go hand in hand with the spirit of Indonesia nationalism. In the terms of Muhammadiyah, it is to taking back Papua in the hold of motherland. With such political identity, the Muslim migrant could not be close to the native Papua who have their own political identity, i.e. Papua-ness. The Muslim migrant is in dominant position, reproduces their political identity through social practices in the field of Islamic organizations. The Muslim migrant has indirectly preserved and perpetuated social construction that Islam is identical with NKRI. Besides that, in the field of politics, the existence of Muslim migrant has made stronger

\footnotetext{
26 Adriana Elisabeth (eds.), Pemetaan Peran, 39.

27 Anthony D Smith, Nasionalisme: Teori, Ideologi, dan Sejarah, trans: Frans Kowa (Jakarta: Penerbit Erlangga, 2003), 180.
} 
government position in their domination over the native Papua, so they do not support the demand of national dialogue and settlement of human rights violence in Papua. Beside the field of Islamic religion, the Muslim Papua also dealt with the Papua-Christian in the field of politics and religion. The following parts will describe how the Muslim Papua contests their identity against the Christian Papua.

\section{Muslim Papua and Christian Papua}

Political identity arena, in this study, consists of the field of Islamic organizations and the field of politics and religion. If the field of Islamic organizations is distinguished according to religion social practices, the field of politics and religion is made out according to, religion political practices that relating the Muslim Papua, Muslim migrant, and Christian Papua. The religion political practices are actions of religion organizations in competition of material and symbolic capitals. As note, this field is not a field of contestation about views and values of religions as take place in the field of Islamic organizations. According to composition of all kind of capital, the Muslim migrant and the Muslim Papua inhabit in subordinated position against the Christian Papua in this field. The most significant value in this field is symbolic capital that is recognition for a religion as culture and identity of the native Papua. The Christian organizations have the biggest capital, as they are identical with the religion of the native Papua native compared with other religions.

The zending mission and Christian churches have significant roles in reproducing knowledge on Papua identity for the reason that the church has paved the way for Papua native to come across modernity including knowing who they are. Mawene in his book: "When Allah touch Papua," explains that the land of Papua is a Christian land starting from interpretation over Ottouw and Geissler's poem when they set their foot in Papua in the first time. ${ }^{28}$ According to him, ${ }^{29}$ historical

\footnotetext{
28 Mawene, Ketika Allah Menjamah Papua (Jayapura: Panitia Perayaan Tingkat Provinsi 148 tahun Injil Masuk di Tanah Papua, 2003), 54-55.

${ }^{29}$ Ibid.
} 
utterances can be interpreted its meaning as formula of conquering which mean that all land and people in Papua were declared as belong to Allah commencement for that time; and Allah is almighty over Papua and the willing should be obeyed. Meanwhile, from formula of votum, those utterances mean that it is praying covering both all-spiritual and material life of Papua native beginning from that time.

In addition, the chairman of Baptist Church of Papua, Rev. Socrates Sofyan Yoman in his book the Elimination of Melanesia ethnic portrays roles of the Christian Churches as follow. ${ }^{30}$ The first, coming of Christian in Papua bring messages of moral, human rights, and problems of Papua. The second, there is a racial and discrimination in the national level in Indonesia. For example, the church in West Java has been closed by local government with the reason no permission from Muslim majority but the development of mosques in Papua is widespread and Islamic law is put into practice in Aceh. The third, exploring the root of Papua problems in history of Papua as victim of colonial, marginalization under New Order, special autonomy and division of provinces, and elimination of Melanesian race. The shame outlook also is written by Agus Alua, a Catholic priest in his book, West Papua: from colonial to colonial. $^{31}$

The classification of Papua as Christian is a form of politization of religion in Papua. The Catholic Churches has different opinion with Christian churches. Fr Saul Wanimbo OFM talks about that strategy of struggle of Papua native bring into play church's propaganda in the context of searching out the right of self-determination. ${ }^{32}$ It can be traced further from the term of Papua as land of peace and the struggle of Papua for independence is blessed by the God. When the religion grows to be political interest, it could not do task of freedom because its essential roles has been curved. ${ }^{33}$ More to the point, that identification is

30 Socrates Sofyan Yoman, Orang Papua Bukan Separatis, Makar, dan OPM, Jayapura: Lembaga Rekonsiliasi hak-Hak Asasi Masyarakat Koteka, 2005).

31 Agus Alua, Papua Barat Dari Pangkuan Ke Pangkuan, Suatu Ikbtisar Kronologis: Seri Pendidikan Politik Papua No. 2 (Jayapura: STFT Fajar Timur, 2006).

32 Arwam, Mark Rumbiak, Ketika Ideologi Sebuah Bangsa Tiba Di Persimpangan Jalan, Solusi Damai Jilid 1, (Yogyakarta: Yogyakarta, 2003), 88.

${ }^{33}$ Ibid. 
rejected by Bishop of Jayapura, Leo Laba Ladjar OFM, for the reason that the recognition is only esoteric. In that context, reason of religion is not meant as theological construction because the Papua native has Melanesia system of belief that is different with Christian. Christian and Melanesia identity is put into discourse to bring together all of Papua native to hold the Papua freedom movement.

The religion political practices, signifies identity contestation in Papua, can be seen in those phenomena as follow: rejection against founding of great mosque in Manokwari by Christian Papua in 2005, proposing the draft of local government regulation on Manokwari as holy city in 2007, rejection against establishment of STAIN (State Islamic Institute) of Al-Fatah Jayapura in 2007, and rejection against founding of mosques in Pegunungan Tengah in 2007. This summary only gives explanation the rejection against STAIN where the symbolic capital used is tradition. The case is started from buying of land for campus building by STAIN to Kaigere tribe. Association of Indonesian priest in Jayapura said that the transaction has gone against adat regulation because no permission from the great ondoafi (leader of set of tribes). Nevertheless, according to vice leader of Adat Council of Papua, each of tribe has their own mechanism in transaction of land. To get the same position in this contest of power, STAIN Al-Fatah inquired Thaha M. Alhamid, the founder of SMP/MMP, to cope this problem. Thaha get by this problem by saying to Governor of Papua that STAIN will be used for empowerment of the native Papua, so Papua could be land of peace in the future because all has been educated in Papua system. The interest behind the Papua-Christian may be to maintain domination over Muslim, but the interest behind Thaha might be also strengthening the existence of Islam in Papua. In that contest of identity, Papua-Muslim gets inflation of capital since the governor accepted the establishment the institute.

Based on those political practices of religion organizations, it can be found out religion habitus that determine those political actions. For example, development of STAIN Al-Fatah is a political practice by the Muslim migrant that being influenced by religion habitus i.e. developing of Islamic missionary and the field of politics and religion that places the 
Muslim migrant is in subordinated position. The rejection against Great Mosque and STAIN AL-Fatah point out a religion habitus of the Christian Papua that less moderate and the field of politics and religion that put them in dominant position. The power struggle in the field of politics and religion also is undertaken through construction of discourse by religion organizations that represent their religion identity. The Christian Papua, that is on the dominant position in this field, said that Christian is the legitimate religion and culture of Papua native. It has been doxa in Papua. Meanwhile, according to them, Islam is for religion of migrants or Indonesian-Malay. The Muslim migrant only develops discourses that their presence in Papua is needed for the interest of development. Islam as religion of the native Papua, constructed by the Muslim Papua is heterodoxy. Therefore, that, the dominant identity in the field of politics and religion in Papua, is the Christian Papua. It has been internalized through discourses, so it has created religion's habitus of the Christian Papua. Furthermore, it has been objectified through representations in religion, social, and political practices, for the common in everyday life.

If it is traced further, both the Muslim Papua and the Christian Papua have the shame habitus before Papua integration into Indonesia that is family religion. Nevertheless, the end of New Order, it looks like change of habitus Christian Papua from moderate into fewer moderates and from open into relatively closed. They use traditions and culture as capital symbolic to prevent development of the Muslim migrant in Papua. In identity contestation, the Muslim migrant do not have significant role because they are not part of the native Papua. It is different with the Christian migrant that can collaborate with Christian Papua to keep up Christian domination over Muslim in Papua. In cases of STAIN Al-Fatah, the conflict started between the Christian migrant, represented by Indonesia Priest Association (Asosiasi Pendeta Indonesia), and the Muslim migrant, represented by Islamic Private Foundation (Yayasan Wiraswasta Islam). It could not develop into violence conflict because the Muslim Papua and the Christian Papua can negotiate and prevent such conflict. The negotiation is possible because both of them come from the same culture and religion habitus, i.e. the culture of 
family religion. After identifying the identity contestation in the field of politics and religion, I arrive into conclusion in the next part.

\section{Picture 1}

The Configuration of Social Agents and Identity Politics Arena in Papua

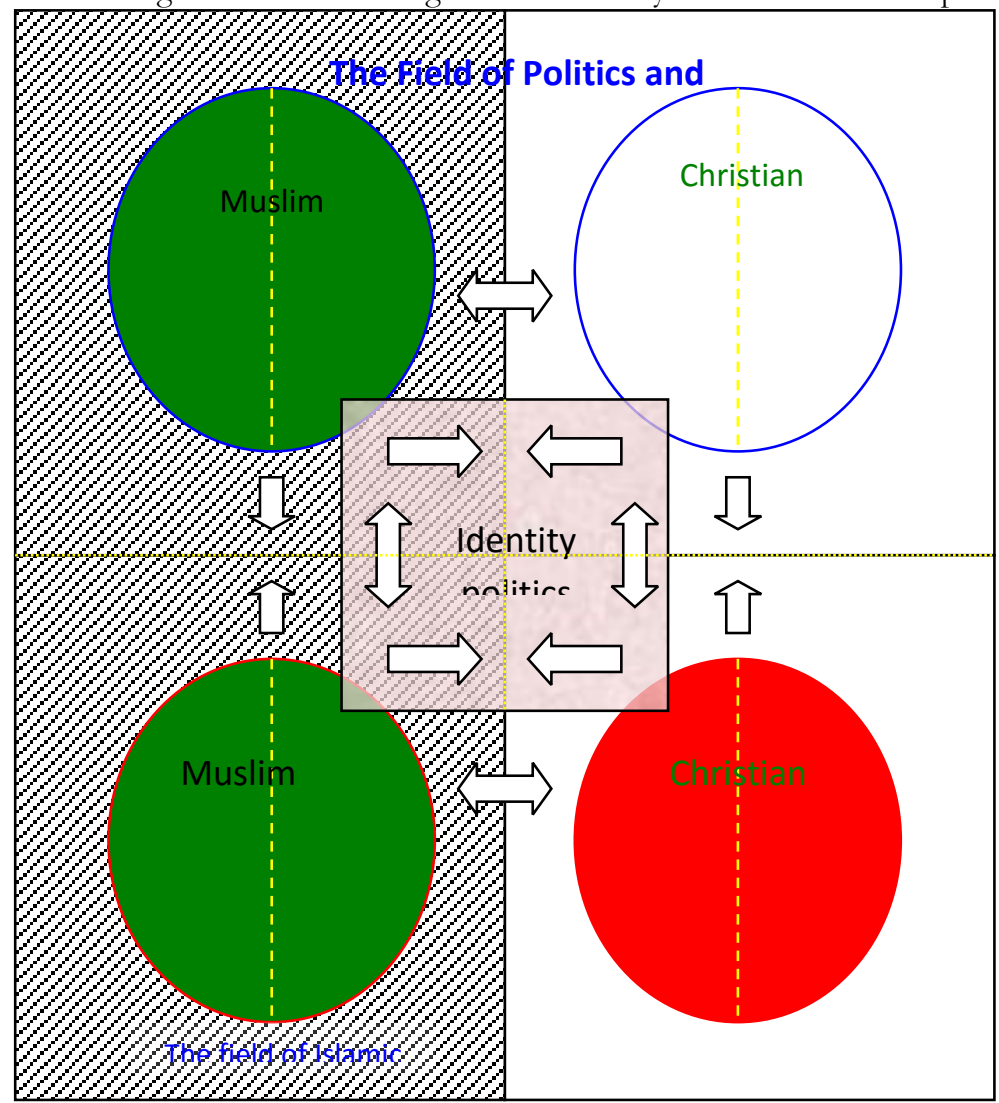

Source: interview data (processed)

$$
\Rightarrow \quad=\text { contestation } \Rightarrow \quad \text { coalition }
$$

\section{Conclusion}


Based on above description, it can be concluded as follow. The first, the Muslim Papua, which is in subordinated position, attempts to get recognition of its cultural identity that fluid in the middle of special autonomy in Papua. The second, the Muslim Papua that in subordinated position in the field of Islamic organizations contest its cultural identity to the Muslim migrant by construction of Papua political identity represented in the discourse of Islam as rahmatan lil Papua (Papua as land of peace), and also practices of human right struggle for the native Papua. The third, the Muslim Papua that in subordinated position in the field of politics and religion, contest its cultural identity with the Christian Papua by construction Islam is the religion of the native Papua and practices of conflict's mediation between the Muslim and the Christian Papua, which related with the development of mosques and Islamic schools. The strategy of Muslim Papua in struggle for recognition of its cultural identity is undertaken by formulation of its identity fluidly and acculturation between Papua-ness and Islam-ness in the field of identity politics in Papua, and also by internal consolidation through establishment of Papua Muslim Assembly (MMP).

Refer Collin, relation between the Muslim Papua and the Christian Papua is outsider with position and insider within relation. ${ }^{34}$ They live together and share with the same history, but the Muslim Papua thinks that they have a different identity and position with the Christian Papua. Refers to Simmel conception on the stranger, the Muslim Papua can be said as the stranger in both Muslim and Christian community. ${ }^{35}$ The Muslim migrant do not like the political orientation of the Muslim Papua that be closer to the Christian Papua concerning with the issue of human right violence. Nevertheless, the Muslim migrant needs the existence of Muslim Papua to negotiate and relate the Muslim community with the Christian Papua in social issues such as the establishing of mosques and Islamic schools.

34 Collins, Patricia Hill, Black Feminist Thought: Knowledge, Consciousness, and the Politics of Empowerment (New York: Routledge, 2000), 10.

35 Simmel, Georg, "On Individuality and Social Forms", ed. Donald. N. Lavine (Chicago and London: The University of Chicago Press, 1993). 
Refers to Bourdieu, the association of Papua to Christian is the dominant cultural identity in the field of politics and religion, as Indonesia-ness is the dominant political identity in the field of Islamic organizations. Both of them are resulted from the symbolic and power struggle between religious institutions. Both of the field of Islamic organizations and the field of politics and religion in Papua is laid down inside broader the field of politics that being occupied by the Indonesia and Papua nationalist. If the field of Islamic organizations in Papua stands in structural homology with the field of politics, so the field on politics and religion is different. It is due to the religion as basis on that field is not equal with the political contestation between Indonesia and Papua nationalist. Nevertheless, the field of economy and the field of politics, according to Bishop of Jayapura and secretary general of PDP, influences the field of politics identity. As evidence, the resistances of the Christian Papua against Muslim migrant in the field of politics and religion is carried out to respond experiences of injustices in economic and political field the native Papua is in subordinated position. The identity politics arena and social agents in this study can be seen in picture below to enable of description. It is noted that the picture does not represent all of the complexity of social reality, but only take description on Muslim Papua, Muslim migrant, Christian Papua, and Christian migrant.

According to Bourdieu, social actors construct identity as performative discourse that is developing into domination instrument over the subordinated groups or resistance instrument to the dominant group. Both of the construction of identity is put into practice in objective power relation among social groups. The construction is social process covering socialization, internalization, objectifications, and inculcation continually. That social process is carried out by social practices, socialization in family and community, ritual religion practices, or discourse construction. If social boundaries are socially constructed, so cultural identity become fluid. This opinion is accordance with Stuart Hall that cultural identity is not essence but a matter of searching of position. As its implication, cultural identity contains of identity politics that is a politics of searching for position in certain society. Cultural identity as representation is not permanent because it is incomplete 
social construction but always in changes process. Compared with Geertz and Barth, Bourdieu concepts in analyzing of Papua is more relevant because Papua identity is not a matter of primordial attachment and Papua identity is not cultural identity but more a political identity.

\section{Bibliography}

Alua, Agus A. Dialog Nasional Papua dan Indonesia 26 Februari 1999: Seri Pendidikan Politik Papua No. 2. Jayapura: STFT Fajar Timur, 2002. . Karakteristik Dasar Agama-agama Melanesia. Jayapura: STFT Fajar Timur, 2006.

- Papua Barat dari Pangkuan ke Pangkuan, Suatu Ikhtisar Kronologis: Seri Pendidikan Politik Papua No. 2. Jayapura: STFT Fajar Timur, 2006.

Athwa, Ali. Islam atau Kristenkah Agama Orang Irian?. Jakarta: Pustaka Da'I, 2004.

Arwam, Mark Rumbiak. Ketika Ideologi Sebuah Bangsa Tiba di Persimpangan Jalan, Solusi Damai Jilid 1. Yogyakarta: Yogyakarta, 2003.

Barth, Fredrik. "Introduction" in Fredrik Barth (ed.), Ethnic Group and Boundaries: The Social Organization of Culture Difference. Bergen-Oslo: Universitets Forlaget, 1969.

Bourdieu, Pierre. Language and Symbolic Power, in edited by John B. Thompson, trans. Gino Raymond and Matthew Adamson. Cambridge: Harvard University Press, 1991.

Collins, Patricia Hill. Black. Feminist Thought: Knowledge, Consciousness, and the Politics of Empowerment. New York: Routledge, 2000.

Chauvel, Richard. "Constructing Papuan Nationalism: History, Ethnicity, and Adaptation" in Policy Studies East-West Center Washington, 2005. www.east-westcenter.org.

Elisabeth, Adriana, Muridan S Wijoyo, Rusli Cahyadi, and Sinnal Blegur (eds.). Pemetaan Peran dan Kepentingan Para Aktor dalam Konflik di Papua. Jakarta: Lembaga Ilmu Pengetahuan Indonesia, 2004. 
Geertz, Clifford. 'The Integrative Revolution: Primordial Sentiments and Civil Politics in the New State" in The Interpretation of Cultures. New York: Basic Books, 1973.

Giay, Benny. Menuju Papua Baru: Beberapa Pokok Pikiran Sekitar Emansipasi Orang Papua. Jayapura: Els-ham Papua, 2001.

- Misi Gereja dan Budaya Kekerasan di Tanah Papua, Hidup dan Karya Pdt Herman Saud ketua Sinode GKI di Tanah Papua Masa Bakti 1996-2005. Jayapura: Deiyai, 2006.

Gelpke, J. Sollewijn. "On the Origin of the Name Papua" in Bijdragen tot de Taal-, Land-en Volkenkunde. No: 2, Leiden, 1993.

Hall, Stuart. "Cultural Identity and Diaspora", in Kathryn Woodward (ed.), Identity and Diaspora. London: SAGE Publication, 1999.

Indonesian Law. No. 21/2001 on Special Autonomy of Papua.

International Crisis Group. Asia Briefing N47. Papua: The Dangers of Shutting Down Dialogue, Jakarta/Brussels, 23 March 2006.

Iribaram, Suparto. "Dinamika Kehidupan Umat Islam dalam Pembangunan di Papua". Jurnal Jabal Hikmah. Vol. 1, No. 1, Januari, 2008.

Kamma, F.C. Ajaib di Mata Kita Jilid I. Jakarta: BPK Gunung Mulia, 1981.

Kivimaki, Timo and Rubern Thorning. "Democratization and Regional Power Sharing in Papua/Irian Jaya: Increased Opportunities and Decreased Motivations for Violence", in Asian Survey. Vol. XLII, No. 4, 2002.

Kompas, 19 November 2005.

Mawene. Ketika Allab Menjamah Papua. Jayapura: Panitia Perayaan Tingkat Provinsi 148 tahun Injil Masuk di Tanah Papua, 2003.

McGibbon, Rodd. "Secessionist Challenges in Aceh and Papua: Is Special Autonomy the Solution?". In www.eastwest.org. 
McGibbon, Rodd. "Pitfalls of Papua Understanding the Conflict and its Place in Australia-Indonesia Relations" in Lowy Institute Paper 13. New South Wales: Lowy Institute for International Policy, 2006.

Mote, Octavianus and Danilyn Rutherford. "From Irian Jaya to Papua; the Limit of Primordialism in Indonesia's Troubled East" in Indonesia. No. 72, October 2001.

Simmel, Georg, "On Individuality and Social Forms", edited by Donald. N. Lavine. Chicago and London: The University of Chicago Press, 1993.

Soedarto, Bondan. Sejarah Perjuangan Rakyat Irian Barat. Jayapura: Uncend and Bappeda Provinsi Irian Jaya, 1989.

Smith, Anthony D. Nasionalisme: Teori, Ideologi, dan Sejarah, trans: Frans Kowa. Jakarta: Penerbit Erlangga, 2003.

Tim Sekretariat Keadilan dan Perdamaian Keuskupan Jayapura. Membangun Budaya Damai dan Rekonsiliasi. Jayapura: SKP Keuskupan Jayapura, 2005.

Widjojo, Muridan S. "Dari Persipura ke Otsus: Masyarakat Sipil Papua dan Agenda Damai" in Adriana Elisabeth (ed.), Agenda dan Potensi Damai di Papua. Jakarta: LIPI Press, 2005.

Widjojo, Muridan S (eds.). Papua Road Map: Negotiating the Past, Improving the Present, and Securing the Future. Jakarta: LIPI, 2008.

Yoman, Socrates Sofyan. Orang Papua Bukan Separatis, Makar, dan OPM. Jayapura: Lembaga Rekonsiliasi hak-Hak Asasi Masyarakat Koteka, 2005. 